\title{
Tyramine Kinetics and Metabolism in Cirrhosis
}

\author{
Bahjat A. Faraj, J. Timothy Fulenwider, Eric B. Rypins, \\ Bernard Nordlinger, George L. Ivey, Robert D. Jansen, Farouk M. Ali, \\ Vernon M. Camp, Michael Kutner, Fred Schmidt, and Daniel Rudman, \\ Departments of Radiology (Division of Nuclear Medicine), \\ Medicine (Clinical Research Facility), Surgery, and Biometry, \\ Emory University, Atlanta, Georgia 30322
}

A B S T RA C T Hypertyraminemia is common in hepatic cirrhosis and correlates in severity with encephalopathy. The mechanism of cirrhotic hypertyraminemia has not been established. The alternative possibilities are increased production from tyrosine and impaired degradation by monoamine oxidase. This investigation determined the pharmacokinetics of tyramine after an intravenous bolus injection of $\left[{ }^{3} \mathrm{H}\right]-$ tyramine $(180-200 \mu \mathrm{Ci}, 12 \mathrm{Ci} / \mathrm{mmol} \mathrm{sp}$ act) in 13 cirrhotics and 9 controls. In normals, $\left[{ }^{3} \mathrm{H}\right]$ tyramine levels initially declined rapidly ( $\alpha$-phase) followed by a slower decline ( $\beta$-phase) with an average $t_{1 / 2}$ of $20.8 \mathrm{~min}$. Average normal metabolic clearance rate and production rate were $13.2 \mathrm{liters} / \mathrm{min}$ and $15.4 \mu \mathrm{g} / \mathrm{min}$, respectively. In cirrhotic patients, the plasma disappearance curve for $\left[{ }^{3} \mathrm{H}\right]$ tyramine was qualitatively similar to that of the control subjects with no apparent difference in $\beta$ - $\mathrm{t}_{1 / 2}$ (17.2 min). The hypertyraminemia of cirrhosis resulted primarily from overproduction of tyramine, as the production rate $(32.0 \mu \mathrm{g} / \mathrm{min})$ in these patients was significantly greater $(P<0.05)$ than in controls, whereas the metabolic clearance rate remained normal (average 12.2 liters $/ \mathrm{min}$ ). A difference in ratio of tyramine metabolic products was noted as well. Cirrhotics had a high ratio of plasma 4-hydroxyphenylethanol:4hydroxyphenylacetic acid (60:40 vs. $30: 70)$ as compared with normals. Although the tyramine clearance rates are similar in normals and cirrhotics, different mechanisms may be responsible for catabolism.

\section{INTRODUCTION}

Tyramine concentration is abnormally elevated in the plasma of cirrhotic patients (1). Tyramine is the precursor of octopamine. Octopamine acts as a central "false neurotransmitter" and tyramine acts as an indirect sympathomimetic agent. Both have potent ef-

Received for publication 5 September 1978 and in revised form 1.5 December 1978. fects on circulatory and neurologic functions, which are often disturbed in cirrhotics (1-5). An understanding of the mechanism of the hypertyraminemia of cirrhotic patients is therefore desirable. The accumulation of tyramine in plasma could result from increased production, decreased degradation, or a combination of both effects.

Tyramine is produced by decarboxylation of tyrosine (Fig. 1). Plasma tyrosine is elevated in cirrhotics (6-8), and tyrosine tolerance is impaired (9), therefore more tyrosine is available for tyramine formation than in normals. Tyramine is also produced in the gastrointestinal tract by bacterial decarboxylation of tyrosine and may enter the systemic circulation via portasystemic shunts.

Tyramine is degraded by monoamine oxidase, of which the major proportion is located in the liver. Accordingly, tyramine degradation could be delayed in cirrhosis because of hepatocellular disease, diminished hepatic blood flow, or both.

In this study, we have measured the production rate and metabolic clearance rate of plasma tyramine in normals and in cirrhotics with a pharmacokinetic technique. The kinetics of tyramine were correlated with the clinical status of the liver patients, the fasting plasma tyrosine, and the tyrosine tolerance. A hypothesis relating hypertyraminemia and hypertyrosinemia was developed from the results.

\section{METHODS}

\section{Materials}

$\left[{ }^{3} \mathrm{H}\right] \mathrm{T}$ yramine $(11.6 \mathrm{Ci} / \mathrm{mmol} \mathrm{sp}$ act) was obtained from New England Nuclear (Boston, Mass.). Radiochemical purity, evaluated by analytic thin-layer chromatography with three different solvent systems (10), was $>98 \%$. Tyramine and octopamine were purchased from Sigma Chemical Co. (St. Louis, Mo.). $p$-Hydroxyphenylacetic acid was obtained from Aldrich Chemical Co., Inc. (Milwaukee, Wis.), and $p$ hydroxyphenethanol was synthesized according to a published procedure of Kiefer (11). The antibody against 


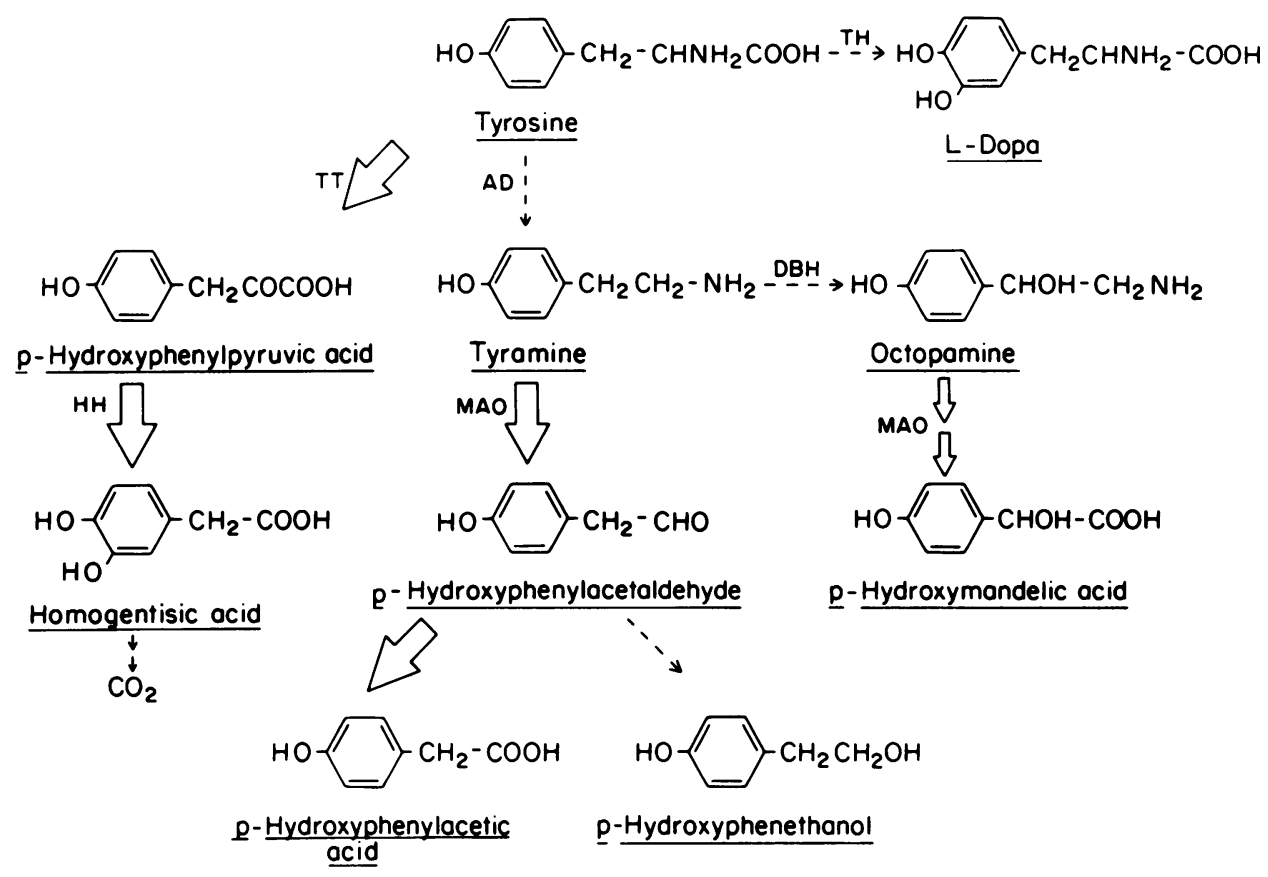

FIGURE 1 Biosynthesis and metabolism of tyramine. In the enzyme system, TT denotes tyrosine transaminase; $\mathrm{TH}$, tyrosine hydroxylase; $\mathrm{AD}$, aromatic amino acid decarboxylase; $\mathrm{DBH}$, dopamine- $\beta$-hydroxylase; $\mathrm{HH}$, 4-hydroxyphenylpyruvic acid oxidase; and MAO, monoamine oxidase.

tyramine was prepared according to the method of Faraj et al. (12). Radioactivity was measured in a liquid scintillation, spectrometer (Beckman LS-330, Beckman Instruments, Inc., Spinco Div., Palo Alto, Calif.) using a scintillation fluid (ACS, Amersham/Searle Corp., Arlington Heights, Ill., counting efficiency, $40 \%$ ).

\section{Subjects}

The control group consisted of 11 healthy adult volunteers, 9 males and 2 females, with no history of hepatobiliary disease and with normal conventional liver tests. The experimental group consisted of 13 patients with cirrhosis, 9 males and 4 females, ages 19-63 yr ( 7 Laennec's, 2 primary biliary, 2 postnecrotic, and 2 chronic active hepatitis with cirrhosis). Cirrhosis was documented by liver biopsy. All subjects gave informed consent. The investigation was approved by the Emory University Clinical Investigation Committee. The clinical data of group II was summarized in Tables I and II.

Each cirrhotic patient received a full liver evaluation before commencement of the $\left[{ }^{3} \mathrm{H}\right]$ tyramine studies, as follows. Serum levels of serum glutamic oxaloacetic transaminase, alkaline phosphatase, albumin, bilirubin, and prothrombin times were measured according to standard laboratory techniques. A modified child's classification was used to grade the severity of liver disease. Fasting venous plasma ammonia quantitation was measured colorimetrically by a modified method of Forman (13). Quantitative tests of hepatic function included galactose elimination capacity (14) and antipyrine clearance and half-life $(15,16)$.

Neurologic and electroencephalographic evaluations were done according to Parsons-Smith et al. (17). The clinical history was considered positive for encephalopathy when mental confusion, disorientation, or asterixis had occurred unrelated to gastrointestinal bleeding, electrolyte imbalance, infection, or drugs. Psychometric testing was used to detect more subtle mental aberrations (18). Renal function was assessed by the 24-h endogenous creatinine clearance.

\section{Studies of $\left[{ }^{3} \mathrm{H}\right]$ tyramine kinetics and metabolism}

\section{FASTING PLASMA TYRAMINE AND TYROSINE}

Blood samples for tyramine and tyrosine were drawn from a peripheral vein, chilled to $0^{\circ} \mathrm{C}$ and centrifuged immediately at $500 \mathrm{~g}$ for $10 \mathrm{~min}$; the plasma was then removed and quickly frozen at $-80^{\circ} \mathrm{C}$ until analysis.

\section{Preparation of $\left[{ }^{3} \mathrm{H}\right.$ ]Tyramine for human use}

All liquid vehicles, syringes, and tubes used in this procedure were sterile and pyrogen-free. Tritiated-labeled tyramine $(250 \mu \mathrm{Ci}, 0.003 \mathrm{mg}, 11.6 \mathrm{Ci} / \mathrm{mmol}, 0.25 \mathrm{ml})$ was added to sodium chloride for injection (1 ml, Abbott Laboratories, North Chicago, Ill.), and the mixture was transferred to a beaker. The rinsing process was repeated twice to ensure complete transfer of the radioactive dose. $3 \mathrm{ml}$ of solution was then drawn into a syringe and sterilized by passage through a Millipore filter $(0.22 \mu \mathrm{m}$, Millex, Millipore Corp., Bedford, Mass.) into an evacuated glass tube. To elute any residual radioactivity, the Millipore filter was washed with $10 \mathrm{ml} 0.9 \% \mathrm{NaCl}$. The specific activity of the injected material was determined by counting $10 \mu \mathrm{l}$ of the dose. Aliquots of the $\left[{ }^{3} \mathrm{H}\right]$ tyramine were tested according to the method described in the U. S. pharmacopeia (19) and found to be pyrogen-free.

\section{IN VIVO STUDIES}

$180-250 \mu \mathrm{Ci}$ of $\left[{ }^{3} \mathrm{H}\right]$ tyramine was given intravenously in $10 \mathrm{ml}$ of $0.9 \% \mathrm{NaCl}$ over a period of $10 \mathrm{~s}$. Heparinized 
TABLE I

Cirrhotic Patients: Liver Data Base

\begin{tabular}{|c|c|c|c|c|c|c|c|c|c|c|}
\hline Patient & $\begin{array}{l}\text { Sex and } \\
\text { age, yr }\end{array}$ & $\begin{array}{c}\text { Disease } \\
\text { status }\end{array}$ & $\begin{array}{c}\text { Type of } \\
\text { shunt }\end{array}$ & SGOT $^{*}$ & $\begin{array}{c}\text { Total } \\
\text { bililirubin }\end{array}$ & Albumin & $\begin{array}{c}\text { Total } \\
\text { protein }\end{array}$ & $\begin{array}{c}\text { Alkaline } \\
\text { phosphatase }\end{array}$ & $\begin{array}{l}\text { Galactose } \\
\text { elimination } \\
\text { capacity }\end{array}$ & $\begin{array}{l}\text { Antypyrine } \\
\text { clearance/t }\end{array}$ \\
\hline & & & & $m U / m l$ & $\mathrm{mg} / 100 \mathrm{ml}$ & $\mathrm{g} / 100 \mathrm{ml}$ & $\mathrm{g} / 100 \mathrm{ml}$ & $m U / m l$ & $m g / m i n$ & $\mathrm{ml} / \mathrm{min} / \mathrm{h}$ \\
\hline Normal & & & & $7-40$ & $0.1-1.0$ & $3.5-5.0$ & $6.0-8.0$ & $30-85$ & $360-540$ & $58 / 16$ \\
\hline J.R. & M-52 & Postnecrotic cirrhosis & Nonselective & 55 & 1.2 & 1.5 & 5.0 & 73 & 280 & - \\
\hline I.S. & F-53 & Primary biliary cirrhosis & Nonselective & 127 & 3.2 & 3.8 & 7.6 & 455 & 198 & $14 / 25$ \\
\hline R.S. & M-38 & Laennec's cirrhosis & Nonselective & 73 & 2.5 & 4.2 & 7.6 & 74 & 279 & - \\
\hline R.D. & M-19 & Chronic active hepatitis & Selective & 137 & 4.08 & 4.0 & 6.5 & 238 & - & - \\
\hline E.D. & F-40 & Chronic active hepatitis & Selective & 121 & 1.9 & 3.1 & 6.2 & 34 & 336 & - \\
\hline J.T. & M-39 & Laennec's cirrhosis & Selective & 105 & 8.3 & 2.8 & 6.1 & 266 & 267 & - \\
\hline L.S. & F-58 & Laennec's cirrhosis & Nonselective & 42 & 1.32 & 3.4 & 6.3 & 75 & 244 & $26 / 14$ \\
\hline H.R. & M-39 & Laennec's cirrhosis & Preoperative & 63 & 6.6 & 2.1 & 7.1 & 411 & 282 & $6.4 / 105$ \\
\hline B.M. & M-63 & Cryptogenic cirrhosis & Nonselective & 81 & 1.36 & 3.4 & 7.1 & 78 & 249 & $22.4 / 34$ \\
\hline R.G. & M-60 & Laennec's cirrhosis & Selective & 21 & 1.3 & 4.4 & 6.8 & 148 & - & - \\
\hline H.E. & M-55 & Laennec's cirrhosis & Selective & 18 & 1.01 & 3.7 & 6.4 & 59 & 392 & $12 / 27$ \\
\hline G.B. & M-51 & Primary biliary cirrhosis & Preoperativ & 76 & 2.0 & 3.7 & 7.6 & 93 & 203 & $17.5 / 28$ \\
\hline B.B. & F-50 & Laennec's cirrhosis & Nonselective & 67 & 2.4 & 3.0 & 6.6 & 135 & 450 & $58.6 / 16$ \\
\hline
\end{tabular}

* Serum glutamic oxaloacetic transaminase.

blood samples $(10 \mathrm{ml})$ were drawn at $1,3,5,7,10,12,15$, $20,30,40,50,60,70$, and $80 \mathrm{~min}$ after dose administration. The samples were centrifuged immediately as above, and then the plasma was removed and quickly frozen at $-80^{\circ} \mathrm{C}$ until analysis. Urine samples were collected into polyethylene bottles containing $10 \mathrm{ml} 6 \mathrm{~N} \mathrm{HCl}$ at 6 -h intervals for 2 consecutive $d$ to ensure complete excretion of the radioactivity. The samples were frozen at the end of the collection and stored at $-80^{\circ} \mathrm{C}$ until analysis.

\section{Analytical methods}

\section{Endogenous Tyramine in Plasma}

Extraction procedure. Tyramine in plasma (usually $1 \mathrm{ml}$ ) was extracted according to the following procedure. To an aliquot of plasma, an equal volume of $6 \% \mathrm{wt} / \mathrm{vol} 5$-sulfosalicylic acid (Eastman Organic Chemicals Div., Eastman Kodak Co., Rochester, N. Y.) was added and the mixture was shaken vigorously (vortex for $1 \mathrm{~min}$ ). Upon centrifugation (500g for $20 \mathrm{~min}$ ), an aliquot of the supernate ( $\mathrm{pH} 1.5$ ) was removed and placed in a 50-ml glass-stoppered centrifuge tube (Kontes Co., Vineland, N. J.). Upon addition of $\mathbf{2} \mathbf{g}$ $\mathrm{NaCl}, 0.3 \mathrm{~g}$ anhydrous $\mathrm{Na}_{2} \mathrm{CO}_{3}, 4 \mathrm{ml}$ of $0.5 \mathrm{M}$ buffer (sodium borate, adjusted to $\mathrm{pH} 10.5$ with $10 \mathrm{~N} \mathrm{NaOH}$ ), and $30 \mathrm{ml}$ of ethyl acetate, the mixture was shaken (model S-500, Kraft Apparatus, Inc.,) for $30 \mathrm{~min}$ and then centrifuged for $10 \mathrm{~min}$. An aliquot $(25 \mathrm{ml})$ of the organic phase was removed. To the two-phase mixture, $10 \mathrm{ml}$ of ethyl acetate was added after shaking and centrifuging as above, $10 \mathrm{ml}$ of solvent was withdrawn. The combined fractions of ethyl acetate $(35 \mathrm{ml})$

TABLE II

Cirrhotic Patients: Liver, Kidney, and Heart Data Base

\begin{tabular}{|c|c|c|c|c|c|c|c|c|c|}
\hline Patient & $\begin{array}{l}\text { Creatinine } \\
\text { clearance }\end{array}$ & $\begin{array}{l}\text { Clinical } \\
\text { encepha- } \\
\text { lopathy }\end{array}$ & $\begin{array}{l}\text { Child's } \\
\text { classi- } \\
\text { fication }\end{array}$ & $\begin{array}{l}\text { Cardiac } \\
\text { output }\end{array}$ & Ammonia & Tyrosine & $\begin{array}{c}\text { Tyrosine } \\
\text { tolerance } \\
\text { score }\end{array}$ & Tyrosine & $\begin{array}{c}\text { Plasma } \\
\text { tyramine }\end{array}$ \\
\hline & $\mathrm{ml} / \mathrm{min}$ & & & liter/min & $\mu g / 100 \mathrm{ml}$ & $\mu$ mollliter & $\mu \mathrm{mol} / \mathrm{h} / \mathrm{liter^{-1 }}$ & $t_{1 / 2}$ & $n g / m l$ \\
\hline Normal & $95-105$ & 0 & G5 & $5.4-4.0$ & $50-60$ & $60-80$ & $370-400$ & $291-377$ & $0.8-1.5$ \\
\hline J.R. & 82 & 0 & G9 & 6.54 & 57 & 117 & - & & 1.31 \\
\hline I.S. & 61 & 0 & G8 & 3.27 & 40 & 135 & 1,795 & 458 & 4.30 \\
\hline R.S. & 110 & 0 & G6 & 5.43 & 135 & 220 & 1,123 & 397 & 2.25 \\
\hline R.D. & 118 & 0 & G7 & - & 58 & 174 & - & & 3.60 \\
\hline E.D. & 104 & 0 & G6 & 7.84 & 70 & 106 & - & & 2.15 \\
\hline J.T. & 103 & 0 & G11 & 3.94 & 80 & 228 & 882 & & 2.10 \\
\hline L.S. & 72 & 0 & G7 & 5.84 & 80 & 109 & 1,669 & 499 & 1.25 \\
\hline H.R. & 113 & 0 & G10 & 6.60 & 77 & 265 & - & & 2.4 \\
\hline B.M. & 90 & 0 & G7 & 4.56 & 109 & 144 & - & & 1.87 \\
\hline R.G. & 67 & 0 & G6 & - & - & 126 & - & & 3.0 \\
\hline H.E. & 69 & 0 & G5 & - & 35 & 100 & - & & 1.40 \\
\hline G.B. & 103 & 0 & G7 & - & 28 & 88 & - & & 5.02 \\
\hline B.B. & 73 & + & G8 & 4.0 & 52 & 111 & - & & 2.50 \\
\hline
\end{tabular}


were evaporated (N-Evap, Organomation Associates Inc., Northborough, Mass.) to dryness under nitrogen at $40^{\circ} \mathrm{C}$. The residue was reconstituted for radioimmunoassay in $0.2 \mathrm{M}$ sodium phosphate buffer ( $\mathrm{pH} 7.4$ ).

Radioimmunoassay procedure. The method used was a modification of that described by Faraj et al. (12). In $12 \times 75$ mm plastic tubes (Lab-Tek culture tube, Lab-Tek Products, Div. Miles Laboratories Inc., Naperville, Ill.) were placed $0.3 \mathrm{ml}$ of $0.5 \%$ bovine serum albumin wt/vol in $0.2 \mathrm{M}$ sodium phosphate buffer solution $(\mathrm{pH} 7.4)$. We then added $0.1 \mathrm{ml}$ of antibody solution $(1: 50), 0.1 \mathrm{ml}$ of $\left[{ }^{3} \mathrm{H}\right]$ tyramine (0.16 $\mathrm{ng}, 7,500 \mathrm{cpm}$ ) in phosphate buffer, and either unlabeled tyramine (0.5-10 ng for standard curve) or $0.1-\mathrm{ml}$ aliquot of the sodium phosphate buffer ( $\mathrm{pH} 7.4$ ) containing the extracted tyramine. The tubes were capped and incubated at $4^{\circ} \mathrm{C}$ for $2 \mathrm{~h}$. Antibody-bound $\left[{ }^{3} \mathrm{H}\right]$ tyramine was separated from tyramine by the addition of $0.5 \mathrm{ml}$ aqueous polyethylene glycol $6,000(30 \% \mathrm{wt} / \mathrm{vol})$ as described by Cheung and Slaunwhite (20). The tubes were vortex mixed vigorously and centrifuged $\left(2,000 \mathrm{~g}, 4^{\circ} \mathrm{C}\right)$ for $40 \mathrm{~min}$. The percentage of free $\left[{ }^{3} \mathrm{H}\right]$ tyramine in the sample was determined by measuring the radioactivity in $0.2 \mathrm{ml}$ of the supernate. The ${ }^{3} \mathrm{H}$ was measured in a liquid scintillation spectrometer. Each sample was assayed in triplicate. All samples were counted to $\pm 2 \%$ error. Within- and between-assay variation was assessed for tyramine by assay of plasma samples in the same as well as in a different assay $(n=30)$. Intra- and interassay coefficients of variation were 8.1 and $6.7 \%$, respectively, for tyramine in plasma.

\section{ENDOGENOUS PLASMA TYROSINE}

Plasma $(0.5 \mathrm{ml})$ was deproteinized with an equal volume of $5 \%$ sulfosalicylic acid solution and centrifuged at $500 \mathrm{~g}$ for $20 \mathrm{~min}$ to precipitate protein material. The tyrosine in the supernate was measured on a Beckman amino acid analyzer (Beckman Instruments) according to Benson and Patterson (21).

\section{TYROSINE TOLERANCE}

Subjects were on a daily $80 \mathrm{~g}$ protein diet for $3 \mathrm{~d}$ before the test. After an 8-h overnight fast, each subject ingested $50 \mathrm{mg} / \mathrm{g}$ ideal body wt of L-tyrosine mixed in applesauce. Fasting plasma samples were withdrawn from a peripheral vein at $0,0.5,1.5,3,3.5,6,7.5$, and $9 \mathrm{~h}$ after ingestion. The samples were immediately cooled, centrifuged at $500 \mathrm{~g}$ for $10 \mathrm{~min}$, and the plasma frozen at $-80^{\circ} \mathrm{C}$ until deproteinized and analyzed for free tyrosine. The tyrosine tolerance score was calculated by obtaining the area under the plasma tyrosine concentration vs. time curve using the trapezoidal rule (22).

\section{RADIOASSAY OF $\left[{ }^{3} \mathrm{H}\right]$ TYRAMINE AND ITS METABOLITES}

Determination of total radioactivity in plasma and urine. Aliquots $(0.3 \mathrm{ml})$ of urine and plasma were placed in liquid scintillation vials and counted as above. The total tritium content was expressed as $\mathrm{cpm}^{-1}$ per milliliter of sample. Instrument counting efficiency for ${ }^{3} \mathrm{H}$ was $45 \%$.

Separation of radioactivity in plasma and urine into basic and acidic fractions. The disappearance of $\left[{ }^{3} \mathrm{H}\right]$ tyramine from plasma and the appearance of its metabolic products ( $\left[{ }^{3} \mathrm{H}\right]$ octopamine, $\left[{ }^{3} \mathrm{H}\right] 4$-hydroxyphenethanol, and $\left[{ }^{3} \mathrm{H}\right] 4$-hydroxyphenylacetic acid) were evaluated in each sample as follows: Plasma proteins were precipitated by treatment of the samples with $6 \%$ sulfosalicylic acid solution. The supernatant fraction was extracted with ethyl acetate (fraction A) and evaporated as described earlier. The remaining aqueous phase was made basic and extracted with ethyl acetate (fraction B) and evaporated to dryness as above. The residues from fraction $A\left(\left[{ }^{3} \mathrm{H}\right] 4\right.$-hydroxyphenylacetic acid and $\left[{ }^{3} \mathrm{H}\right] 4$-hydroxyphenethanol) and fraction $\mathrm{B}\left(\left[{ }^{3} \mathrm{H}\right]\right.$ tyramine and $\left[{ }^{3} \mathrm{H}\right]$ octopamine) were reconstituted in $0.3 \mathrm{ml}$ of methanol for radiochromatographic analysis.

Radiochromatographic analysis. The reconstituted residues from fractions $A$ and $B$ were applied to $0.25 \mathrm{~mm}$ thinlayer chromatography plates (silica gel GF; New England Nuclear). The plates were developed to $14 \mathrm{~cm}$ in a system made up of ammonia:methanol:chloroform: $n$-butanol (15:15: 15:55). Under these conditions, $R_{t} s$ of tyramine, octopamine, 4-hydroxyphenylacetic acid, and 4-hydroxyphenethanol were $0.78,0.61,0.25$, and 0.88 , respectively. Spots were visualized by ultraviolet light $(250 \mathrm{~nm})$. A freshly prepared solution of $\left[{ }^{3} \mathrm{H}\right]$ tyramine $(1 \mu \mathrm{Ci})$ was also applied to the plates to provide references. The plates were scraped with an Autozonal scraper (Analabs, Inc., North Haven, Conn.) in 0.5-cm sections and placed in scintillation vials containing $1 \mathrm{ml}$ of methanol. The mixture was shaken vigorously and allowed to stand at least $3 \mathrm{~h}$ before counting. The recovery of tyramine and its metabolites by this procedure is $50-60 \%$, respectively.

\section{Calculation of pharmacokinetic parameters}

\section{ANALYSIS OF CURVES AFTER BOLUS INTRAVENOUS INJECTION OF TRACER DOSE OF $\left[{ }^{3} \mathrm{H}\right]$ TYRAMINE}

The data were analyzed according to the two-compartment pharmacokinetic model with a computerized nonlinear regression analysis. The plasma concentration and specific activity of $\left[{ }^{3} \mathrm{H}\right]$ tyramine as a function of time was expressed as the sum of two exponentials: $\mathrm{Cp}=\mathrm{Ae}^{\alpha t}+\mathrm{Be}^{\beta t}$, where $\mathrm{Cp}$ is the concentration of $\left[{ }^{3} \mathrm{H}\right]$ tyramine in the plasma at any instant in time; $A$ and $B$ are the intercepts on the ordinate of the "fast" and "slow" components, respectively; $e=2.718$; $\alpha$ and $\beta$ are the fractional rate constants, and $t$ is the time in minutes. The area under the plasma concentration vs. time curves (AUC) ${ }^{1}$ was obtained by a computerized nonlinear regression program using a two-compartment open model.

\section{Plasma Clearance rate and PRODUCTION RATE OF TYRAMINE}

Metabolic clearance rate (MCR), also referred to as the plasma clearance rate, represents the volume of plasma completely and irreversibly cleared of $\left[{ }^{3} \mathrm{H}\right]$ tyramine per unit time by all processes of metabolism and excretion. The MCR was calculated according to the method of Broadus et al. (23) from the following equation: MCR $=\mathrm{D} / \mathrm{AUC}$, where $\mathrm{D}$ is the dose of $\left[{ }^{3} \mathrm{H}\right]$ tyramine administered in cpm and AUC is the area under the plasma concentration vs. time curve $(\mathrm{cpm} \times \mathrm{min}$ $\left.\times \mathrm{ml}^{-1}\right)$. The production rate $(\mathrm{PR})$ is the rate of tyramine input into the miscible pool from all sources and was calculated from the equation $\mathrm{PR}=\mathrm{D} / \mathrm{AUC}$ (specific activity) where $\mathrm{D}$ is the $\mathrm{cpm}$ of injected $\left[{ }^{3} \mathrm{H}\right]$ tyramine and AUC is the area under the plasma specific activity vs. time curve $\left(\mathrm{cpm} \times \min \times \mathrm{ng}^{-1}\right)$. The following equation relates MCR and PR in the steady state:

${ }^{1}$ Abbreviations used in this paper: AUC, plasma concentration vs. time curves; MCR, metabolic clearance rate; PR, production rate. 
$\mathrm{PR}=\mathrm{MCR} \times \mathrm{Ci}$, where $\mathrm{Ci}$ is the endogenous tyramine concentration $(\mathrm{ng} / \mathrm{ml})$ in the plasma pool. Tyramine concentration was measured in every specimen and the results are shown in Fig. 2. Half-life was determined by the least squares method from the log-linear terminal portion of the curve.

\section{Statistical analysis}

The results obtained in each series of experiments are expressed as the arithmetic mean and standard error (SEM). The sample means were compared by the Student's $t$ test for paired data when appropriate. Values of $P<0.05$ were accepted as representing significant differences.

\section{RESULTS}

Plasma levels of tyramine and tyrosine; correlations with clinical data. Normal fasting tyrosine was 40-70 $\mu \mathrm{mol} / \mathrm{liter}$. All 13 cirrhotic patients had fasting tyrosinemia (Table II). The four patients who received an oral ty rosine tolerance test also showed marked impairment in the plasma clearance of this amino acid. Normal plasma tyramine was $1.2 \mathrm{ng} / \mathrm{ml}$. Plasma tyramine was elevated in 9 of the 13 cirrhotics (Table II).

The degree of tyrosinemia and tyraminemia was directly correlated with antipyrine half-life and galactose elimination capacity $(r=0.901, P<0.002$; Table I). In addition, plasma tyrosine levels were also significantly correlated with prothrombin time $(r=0.750$, $P<0.003)$ and the child's score $(r=0.55, P<0.05)$. Only 1 of the 13 patients had clinical encephalopathy. 10 cirrhotics had mild psychomotor impairment. Cardiac output and creatinine clearance were normal in $67 \%$ of the patients. Neither cardiac output nor creatinine clearance correlated significantly with plasma tyrosine or tyramine.

Plasma tyramine concentrations at determined intercals. In both the cirrhotic and the control subjects, the endogenous tyramine concentration in plasma determined in samples obtained at various time inter-

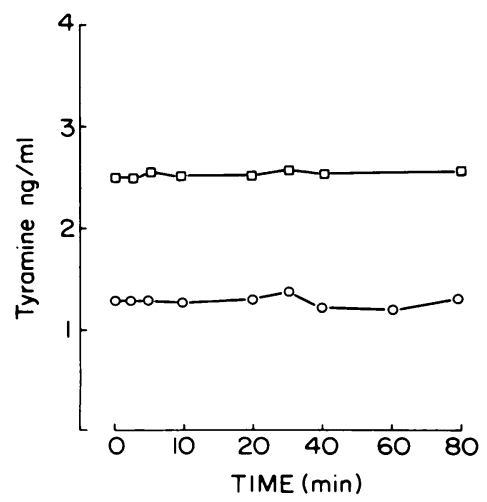

Figure 2 Average endogenous plasma tyramine concentrations ( $\mathrm{ng} / \mathrm{ml}$ ) in cirrhotics $(\square)$ and control subjects $(O)$ evaluated at determined intervals after intravenous administration of $\left[{ }^{3} \mathrm{H}\right]$ tyramine to each group. vals after the administration of $\left[{ }^{3} \mathrm{H}\right]$ tyramine to both groups remained constant (Fig. 2).

$\left[{ }^{3} \mathrm{H}\right]$ Tyramine metabolism. In normal subjects, the plasma disappearance curve for $\left[{ }^{3} \mathrm{H}\right]$ tyramine and total ${ }^{3} \mathrm{H}$ indicated a multiexponential pattern becoming monoexponential at $\cong 8-10 \mathrm{~min}$ after dose administration. For $\left[{ }^{3} \mathrm{H}\right]$ tyramine two components were resolvable from the curves of $\left[{ }^{3} \mathrm{H}\right]$ tyramine concentration $(\mathrm{cpm} / \mathrm{ml})$ and $\left[{ }^{3} \mathrm{H}\right]$ tyramine specific activity $(\mathrm{cpm} / \mathrm{ng})$ (Fig. 3A and B). The initial distribution phase $(\alpha)$ and the elimination phase $(\beta)$ both proceeded rapidly with average half-life ( $\beta$-phase) of $20.82 \mathrm{~min}$. The calculation of MCR and PR revealed that in normal subjects average MCR was 13.2 liters/min and PR was 15.4 $\mu \mathrm{g} / \mathrm{min}$ (Table III), respectively. Furthermore, total ${ }^{3} \mathrm{H}$ was also determined, allowing the measurement of the pattern of all the tyramine metabolites in plasma. There was a 10-fold difference between ${ }^{3} \mathrm{H}$ levels and $\left[{ }^{3} \mathrm{H}\right]$ tyramine concentrations (Fig. $3 \mathrm{~A}$ and B). Radiochromatographic analysis indicated that most ${ }^{3} \mathrm{H}$ in plasma consisted of products obtained from the oxidative deamination of $\left[{ }^{3} \mathrm{H}\right]$ tyramine (4-hydroxyphenylacetic acid and 4-hydroxyphenethanol in the ratio of 70:30).

In patients with cirrhosis, the plasma disappearance curve for $\left[{ }^{3} \mathrm{H}\right]$ tyramine was similar to that of the control subjects with no apparent difference in the half-life $(\beta$-phase, $17.2 \mathrm{~min}$ ). The PR of tyramine (average 32 $\mu \mathrm{g} / \mathrm{min})$ in cirrhotics was significantly greater $(P<0.05)$ than that of normal subjects (average $15.4 \mu \mathrm{g} / \mathrm{min}$ ). In contrast, there was no difference in the MCR of tyramine in cirrhotics (average $12.2 \mathrm{liter} / \mathrm{min}$ ) as compared with control subjects (average 13.2 liters/min) (Table III). The profile of $\left[{ }^{3} \mathrm{H}\right]$ tyramine metabolism in the cirrhotic patient was markedly different when compared with that of the control subjects. There was a fourfold increase in the ratio of 4-hydroxyphenylethanol to that of 4-hydroxyphenylacetic acid in cirrhotic patients as compared with control subjects $(60: 40$ vs. 30:70 in controls).

After the single intravenous administration of $\left[{ }^{3} \mathrm{H}\right]-$ tyramine to normal subjects, radioactivity was present in the urine $6 \mathrm{~h}$ after dose administration: $48 \mathrm{~h}$ later $90-95 \%$ of the administered radioactivity had been recovered in the urine. Chromatographic analysis of the urine showed that $\left[{ }^{3} \mathrm{H}\right] 4$-hydroxyphenylacetic acid accounted for $80-85 \%$ of the radioactivity, whereas $\left[{ }^{3} \mathrm{H}\right]$ tyramine accounted for only $2-5 \%$ (Fig. 4). This same pattern was found in the cirrhotics.

\section{DISCUSSION}

For more than $20 \mathrm{yr}$, hypertyrosinemia and impaired tyrosine tolerance have been recognized as common metabolic disorders in cirrhosis. More recently, plasma accumulations of two amines derived from tyrosine, 

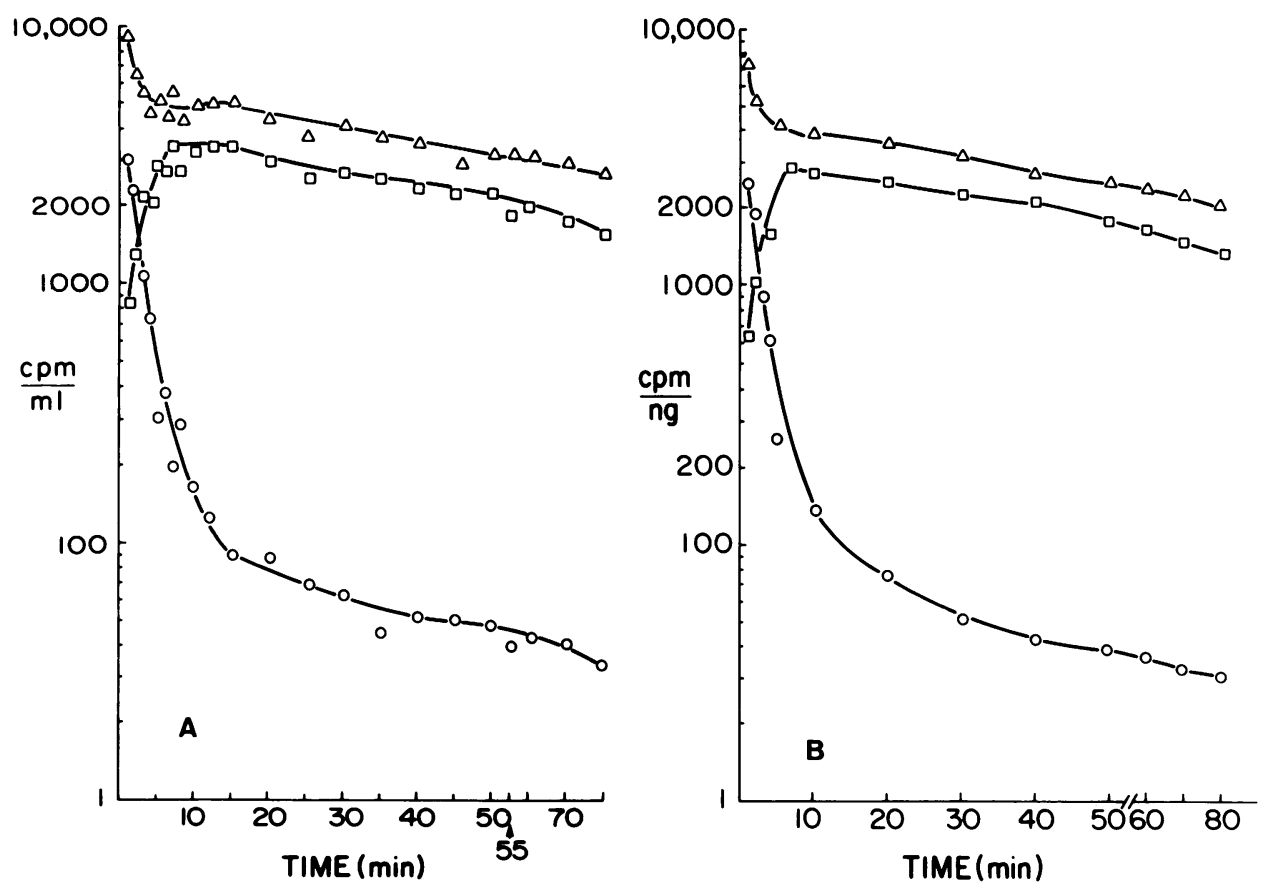

Figure 3 Average plasma levels of $\left[{ }^{3} \mathrm{H}\right]$ tyramine, its metabolites, and ${ }^{3} \mathrm{H}$ disappearance curves after single rapid intravenous injection of $\left[{ }^{3} \mathrm{H}\right]$ tyramine $(220 \mu \mathrm{Ci}, 11.6 \mathrm{Ci} / \mathrm{mmol}$ sp act $)$ to nine normal volunteers. (A) Average plasma $\left[{ }^{3} \mathrm{H}\right]$ tyramine concentration $(\mathrm{cpm} / \mathrm{ml}, \mathrm{O})$, its metabolites $(\mathrm{cpm} / \mathrm{ml}, \square)$, and total ${ }^{3} \mathrm{H}(\mathrm{cpm} / \mathrm{ml}, \triangle)$. (B) Average plasma tyramine specific activity $(\mathrm{cpm} / \mathrm{ng}$, $\mathrm{O})$, its metabolites (cpm/ng, $\square)$, and total ${ }^{3} \mathrm{H}(\mathrm{cpm} / \mathrm{ng}, \Delta)$. The average value for endogenous plasma tyramine was $1.2 \mathrm{ng} / \mathrm{ml}$.

TABLE III

Pharmacokinetic Parameters Obtained after the Single Intravenous Injection of Tritiated Tyramine to Patients with Cirrhosis

\begin{tabular}{lccc}
\hline Subject* & $\beta-\mathrm{t}_{1 / 2}$ & PR & MCR \\
\hline & $m i n$ & $\mu g \times \min ^{-1}$ & liter $\times \min ^{-1}$ \\
K.G. & 21.6 & 20.2 & 15.6 \\
J.R. & 11.0 & 26.4 & 20.2 \\
I.S. & 57.3 & 49.1 & 11.4 \\
R.S. & 33.0 & 22.8 & 10.14 \\
R.D. & 4.80 & 59.3 & 16.5 \\
E.D. & 9.60 & 18.3 & 8.5 \\
J.T. & 4.0 & 10.5 & 5.0 \\
L.S. & 5.54 & 17.8 & 14.3 \\
H.R. & 7.12 & 56.0 & 23.3 \\
B.M. & 4.0 & 9.1 & 4.9 \\
R.G. & 16.0 & 17.7 & 6.085 \\
H.E. & 31.0 & 2.8 & 2.00 \\
G.B. & 18.6 & 106.4 & 21.2 \\
B.B. & 17.4 & 28.2 & 11.4 \\
& & & \\
Average & 17.2 & 32.00 & 12.2 \\
\pm SEM & \pm 4.30 & \pm 7.90 & \pm 1.88 \\
Control & 20.81 & 15.4 & 13.24 \\
\pm SEM & \pm 1.63 & \pm 3.00 & \pm 2.68 \\
\hline
\end{tabular}

* For clinical status, see Tables I and II. tyramine, and its $\beta$-hydroxylated derivative octopamine, have also been found in cirrhotics (1-5).

The objective of this study is to determine whether tyramine accumulation in plasma is the result of accelerated production or decreased elimination. In

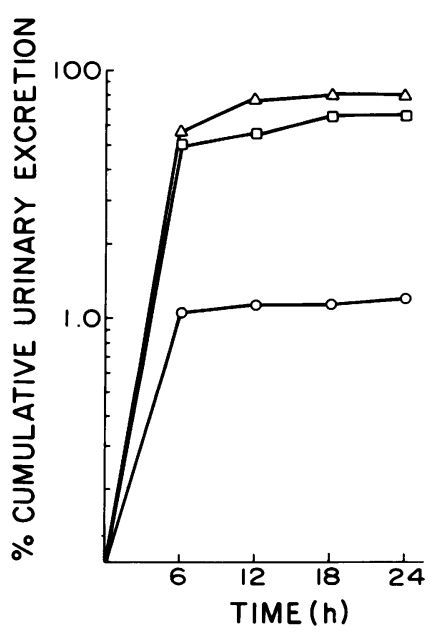

FIGURE 4 Average cumulative urinary excretion of $\left[{ }^{3} \mathrm{H}\right]-$ tyramine $(O)$, its metabolites $(\square)$, and total ${ }^{3} \mathrm{H}(\triangle)$ to nine normal volunteers after a single intravenous administration of $\left[{ }^{3} \mathrm{H}\right]$ tyramine. The percentages are based on total radioactivity $(\triangle)$ administered to the subjects. 
using the pharmacokinetic method to analyze tyramine kinetics, four conditions must be satisfied: (a) plasma level of endogenous tyramine must remain constant during the experiment; $(b)$ the exogenous $\left[{ }^{3} \mathrm{H}\right]$ tyramine must equilibrate with the endogenous plasma compound and then be metabolized in an identical manner with the latter material; $(c)$ the plasma pool of endogenous tyramine must remain constant during the test; and $(d)$ the plasma disappearance curve of $\left[{ }^{3} \mathrm{H}\right]$ tyramine must conform to the two-compartment model. The experimental findings show that within the limits of accuracy of the analytic methods, conditions $a, c$, and $d$ were met. That $\left[{ }^{3} \mathrm{H}\right]$ tyramine was metabolically indistinguishable from unlabeled endogenous tyramine remains an assumption.

The plasma tyramine production rate measurements made in this study do not imply sampling of the total body production of tyramine. Rather, the determinations represent production into that portion of the tyramine pool with which tyramine in plasma is miscible. The rate of tyramine input into the pool being sampled (peripheral plasma) does not detect tyramine input into other noncommunicating pools. An example of such a pool might be tyramine produced in the gut, absorbed into the portal vein, and eliminated by the liver on first pass. This tyramine does not reach the peripheral plasma and so is not measured. It must be noted that the plasma production rate method will not discriminate between endogenously produced tyramine and tyramine reaching the circulation because of decreased first pass clearance through the liver. Our results indicate, however, that once in peripheral plasma, tyramine is cleared in a quantitatively similar manner in normals and cirrhotics.

We found that the hypertyraminemia of cirrhosis results primarily from overproduction of the amine. PR in the cirrhotics was significantly greater than in the controls. The metabolic clearance rate, i.e., plasma cleared of tyramine per minute, elimination half-life, and volume of distribution remained normal. When plasma tyramine was elevated in cirrhotics, the amount of tyramine cleared per minute did not decrease but increased in parallel with the PR. Thus the data indicated that a rise in production was the primary event; as plasma tyramine increased, plasma volume cleared per unit time generally remained constant, and plasma tyramine concentration rose until the amount of tyramine cleared per unit time, i.e. (plasma clearance $\times$ plasma concentration), increased to equal the PR.

We found evidence suggesting that although the MCR was the same in cirrhotics and controls, the clearance mechanism may not be entirely normal in cirrhotics. The metabolic pathways of tyramine are shown in Fig. 1. Monoamine oxidase located both in hepatic and extrahepatic tissues converts tyramine to an aldehyde intermediate which is then oxidized further to 4-hydroxyphenylacetic acid (A) as the major metabolite, and to 4-hydroxyphenethanol (B) as the minor product. In cirrhosis, the ratio of $\mathrm{B}: \mathrm{A}$ is abnormally high. This could reflect an abnormality in hepatic monoamine oxidase obstructing the tyramine A step. Alternatively, if the extrahepatic monoamine oxidase converts preferentially to $B$, the high $B: A$ ratio could mean that in cirrhosis a higher proportion of tyramine is being oxidized in extrahepatic tissues than in the liver.

What is the cause of the increased production of tyramine in cirrhotics? Several clues suggest that the cause is an inability to degrade tyrosine via the normally major hepatic oxidative pathway, tyrosine $\rightarrow$ 4hydroxyphenylpyruvic acid $\rightarrow$ homogentisic acid $\rightarrow$ acid $\rightarrow \rightarrow \mathrm{CO}_{2}$, with consequent overflow into the extrahepatic decarboxylative pathway tyrosine $\rightarrow$ tyramine. Fasting tyrosine was elevated two to four times in all hypertyraminemic patients, and clearance of an oral load of tyrosine was retarded, suggesting impaired capacity of the hepatic oxidative pathway. This process normally metabolizes $>90 \%$ of dietary tyrosine. David et al. (24) have shown that endogenous production of tyramine from tyrosine via decarboxylation becomes a major pathway for the catabolism of tyrosine when the dietary intake of this amino acid increases to three times the minimal daily requirement. Further support for this hypothesis comes from our demonstration of impaired metabolism of both 4-hydroxyphenylpyruvic and homogentisic acids in hypertyraminemic cirrhotics, compatible with blocks at the levels of the two corresponding hepatic oxidases (25). Finally, when dietary tyrosine is increased in cirrhotics, plasma tyrosine and plasma tyramine rise in parallel (1).

It is possible that some of the overproduction of tyramine from tyrosine could result from the gastrointestinal bacterial decarboxylases rather than from the patient's tissue decarboxylases. Portasystemic shunting would permit the bacterial product to circumvent the first pass effect of hepatic monoamine oxidase and enter the peripheral plasma.

With regard to the possible clinical consequences of the accumulations of tyramine and octopamine, Fischer and Baldessarini (2) have suggested that these amines may cause lowering of peripheral resistance with resultant high cardiac output, reduction in renal function, and cerebral dysfunction in cirrhotic patients. In our series, almost all patients had normal cardiac output, creatinine clearance, and electroencephalograms, so our data do not shed light on this issue. However, if the present methods are applied in the future to hyperdynamic, azotemic, or encephalopathic cirrhotic patients, the role of hypertyraminemia in these complications can be examined.

\section{ACKNOWLEDGMENT}

This work was supported in part by grants AM 21646-01 and RR 0039-19 from the National Institutes of Health. 


\section{REFERENCES}

1. Faraj, B. A., P. A. Bowen, J. W. Isaacs, and D. Rudman. 1976. Hypertyraminemia in cirrhotic patients. N. Engl. J. Med. 294: 1360-1364.

2. Fischer, J. E., and R. J. Baldessarini. 1971. False neurotransmitters and hepatic failure. Lancet. II: 75-80.

3. Lam, K. C., A. R. Tall, G. B. Goldstein, and S. P. Miltilis. 1973. Role of a false neurotransmitter, octopamine, in the pathogenesis of hepatic and renal encephalopathy. Scand. J. Gastroenterol. 8: 465-472.

4. Manghani, K. K., M. R. Lunzer, B. H. Billing, and S. Sherlock. 1975. Urinary and serum octopamine in patients with portal-systemic encephalopathy. Lancet II: 943-946.

5. Capocaccia, L., C. Cangiano, A. F. Attili, M. Angelico, A. Cascino, and F. R. Fanelli. 1977. Octopamine and ammonia plasma levels in hepatic encephalopathy. Clin. Chim. Acta. 75: 99-105.

6. Zinneman, H. H., U. S. Seal, and R. P. Doe. 1969. Plasma and urinary amino acids in Laennec's cirrhosis. Am. J. Dig. Dis. 14: 118-126.

7. Sherwin, R., P. Joshi, R. Hendler, P. Felig, and H. D. Conn. 1974. Hyperglucagonemia in Laennec's cirrhosis. N. Engl. J. Med. 290: 239-242.

8. Fischer, J. E., N. Yoshimura, A. Aguirre, J. H. James, M. G. Cummings, R. M. Abel, and F. Deindoerfer. 1974. Plasma amino acids in patients with hepatic encephalopathy: effects of amino acid infusions. Am. J. Surg. 127: 40-47.

9. Levine, R. J., and H. O. Conn. 1967. Tyrosine metabolism in patients with liver disease. J. Clin. Invest. 46: 20122020.

10. Faraj, B. A., P. G. Dayton, V. M. Camp, J. P. Wilson, E. J. Malveaux, and R. C. Schlant. 1977. Studies of the fate of tyramine in dogs: the effect of monoamine oxidase inhibition, portafemoral shunt and coronary artery ligation on the kinetics of tyramine. J. Pharmacol. Exp. Ther. 200: 384-393.

11. Kiefer, E. F. 1972. A rapid convenient preparative procedure for phenethylamines. J. Med. Chem. 15: 214.

12. Faraj, B. A., J. Y. Mu, M. S. Lewis, J. Wilson, Z. H. Israili, and P. G. Dayton. 1975. Determination of plasma and tissue levels of tyramine by radioimmunoassay. Proc. Soc. Exp. Biol. Med. 149: 664-669.
13. Forman, D. T. 1964. Rapid determination of plasma ammonia by ion-exchange technique. Clin. Chem. 10: 497-508.

14. Tygstrup, N. 1966. Determination of hepatic elimination capacity of galactose by single injection. Scand. J. Clin. Lab. Invest. 18: 118-125.

15. Branch, R. A., C. M. Herbert, and A. E. Read. 1973. Determination of serum antipyrine half-lives in patients with liver disease. Gut. 14: 569-573.

16. Brodie, B. B., J. Axelrod, R. Soberman, and B. B. Levy. 1949. The estimation of antipyrine in biological materials. J. Biol. Chem. 179: 25-29.

17. Parsons-Smith, B. G., W. H. J. Summerskill, A. M. Dawson, and S. Sherlock. 1957. The electroencephalograph in liver disease. Lancet. II: 867-871.

18. Rikkers, L., P. Jenko, D. Rudman, and D. Friedes. 1978. Subclinical hepatic encephalopathy: detection, prevalence, and relationship to nitrogen metabolism. Gastroenterology. 75: 462-469.

19. United States Pharmacopeia. XIX. 1975. Pyrogen test. United States Pharmacopeial Convention, Inc., Rockville, Md. 613.

20. Cheung, M. C., and W. R. Slaunwhite, Jr. 1976. Use of polyethylene glycol in separating bound from unbound in radioimmunoassay of thyroxine. Clin. Chem. 22: 299-304.

21. Benson, J. V., and J. A. Patterson. 1965. Accelerated chromatographic analysis of amino acids commonly found in physiological fluids on a spherical resin of specific design. Anal. Biochem. 13: 265-280.

22. Gibaldi, M., and D. Perrier. 1975. Pharmacokinetics. Marcel Dekker, Inc., New York. 293-294.

23. Broadus, A. E., N. I. Kaminsky, J. G. Hardman, E. W. Sutherland, and G. Liddle. 1970. Kinetic parameters and renal clearance of plasma adenosine $3^{\prime}, 5^{\prime}$-monophosphate in man. J. Clin. Invest. 49: 2222-2236.

24. David, J. C., W. Dairman, and S. Udenfriend. 1974. Decarboxylation to tyramine: a major route of tyrosine metabolism in mammals. Proc. Natl. Acad. Sci. U. S. A. 71: 1771-1775.

25. Nordlinger, B., J. T. Fulenwider, B. A. Faraj, R. A. Bethel, and D. Rudman. 1978. Tyrosine metabolism in cirrhosis: acquired alkaptonuria. Surg. Forum. 29: 442-444. 